\title{
Extraction and Purification of Anti-Helicobacter pylori $\operatorname{IgY}$
}

\author{
Phamoh Siriya ${ }^{1}$, Chishih $\mathrm{Chu}^{2}$, Mei-Tsu Chen ${ }^{3}$, Ching-Chu Lo ${ }^{3}$, Shih-Li Huang ${ }^{4} \&$ Tu-Fa Lien ${ }^{1}$ \\ ${ }^{1}$ Department of Animal Science, National Chiayi University, Taiwan, R.O.C. \\ ${ }^{2}$ Department of Microbiology, Immunology, and Biopharmaceutics, National Chiayi University, Taiwan, R.O.C. \\ ${ }^{3}$ Division of Hepatogastroenterology, Department of Internal Medicine, St. Martin De Porres Hospital, Taiwan, \\ R.O.C \\ ${ }^{4}$ Department of Backing Technology and Management, National Kaohsiung University of Hospitality and tourism, \\ Taiwan, R.O.C. \\ Correspondence: Tu-Fa Lien, Department of Animal Science, National Chiayi University, Taiwan, R.O.C. Tel: \\ 886-5-271-7536. E-mail: tflien@mail.ncyu.edu.tw
}

Received: December 5, 2012 Accepted: December 24, 2012 Online Published: February 5, 2013

doi:10.5539/jas.v5n3p132 URL: http://dx.doi.org/10.5539/jas.v5n3p132

\begin{abstract}
The aim of this study was to establish an efficient procedure to produce anti-H. pylori urease IgY from the eggs of the laying hens. Four White Leghorn hens ( 52 weeks old) were immunized intramuscularly with the purified urease of $H$. pylori with aluminum hydroxide gel adjuvant. To increase the specificity and antibody titer, three boosters were given at 2-week intervals following the first injection. After the final immunization, the eggs were collected daily and stored at $4{ }^{\circ} \mathrm{C}$. The yield of yolk proteins were $47.52 \%, 41.07 \%$ and $51.35 \%$ for the methods of dextran sulphate, isopropanol and water-soluble fraction (WSF), respectively. Further, IgY was purified successively by ammonia sulfate, affinity chromatography and ion exchange chromatography for each crude protein. Ammonia sulfate salting produced the IgY with a purity of $37-53 \%$ and the titer of $22.6-29.5 \mathrm{unit} / \mathrm{mg}$. The purity, relative purification folds and titer characteristics of the purified IgY were 85-90\%, 19.63-34.61 and 223.8-273.4 unit/mg protein for affinity chromatography, and 89-92\%, 25.33-47.14 and 288.8-372.4 unit/mg protein for ion exchange chromatography, respectively. This anti-Helicobacter pylori IgY was specific against $H$. pylori usease. Here, we established a simple and inexpensive method to obtain a yield of $90 \%$ purity of the anti-H. pylori IgY in combinations of the WSF method, ammonia sulfate precipitation, and affinity chromatography.
\end{abstract}

Keywords: white leghorn hens, extraction and purification, Anti-Helicobacter pylori, IgY

\section{Introduction}

Most commercial antibodies are produced from rabbits, rats or sheep. However, poultry is more cost-effective to

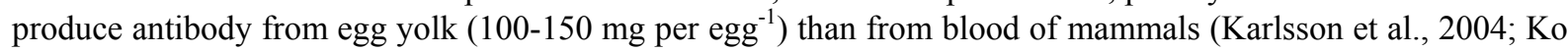
\& Ahn, 2007). In mammalian, the IgG is the most abundant than other four antibodies including IgA, IgM, IgE and IgD. Similar to mammalian IgG in function and structure, IgY (immunoglobin from yolk, so-called chicken IgG.) of poultry is transferred from blood to the egg yolk in a passive process. However, these two antibody types differ in molecular weight (180 Kda for IgY vs $150 \mathrm{Kda}$ for mammalian IgG) (Tini et al., 2002; Zhang, 2003). However, properties regard lipidphilia, and the $\mathrm{pH}$ of isoelectric point revealed that IgY is more lipidphilic and lower pH than IgG (Davalos-Pautoja et al., 2000).

For the wide utilization of the $\operatorname{IgY}$, several methods have been developed to improve the purity and quantity of the IgY purified from egg yolk in more simple and less chemicals (Kim \& Nakai, 1998). In the IgY purification, high concentration of lipids and lipoproteins in egg yolk is one of the major obstacles (Verdoliva et al., 2000). Therefore, various strategies have been used to purify IgY firstly with salt precipitation i.e. ammonium sulfate $\left(\left(\mathrm{NH}_{4}\right)_{2} \mathrm{SO}_{4}\right)$ or sodium sulfate $\left(\mathrm{Na}_{2} \mathrm{SO}_{4}\right)$, followed by centrifugation, alcohol precipitation such as isopropanol (Bade \& Stegemann, 1984), or water-soluble fraction (WSF) and chromatographic methods (Akita \& Nakai, 1992). Further, a simple and automatic filtration system has been developed (Polson et al., 1985). However, gel filtration chromatography and affinity chromatography are still required for final purification (Kim \& Nakai, 1996). With application of mammalian IgG in disease diagnosis or experiments e.g. ELISA, detoxification of toxic materials, and prevention and treatment of diseases (Reilly et al., 1997; Yokoyama et al., 1992), IgY can 
prevent and cure intestinal infectious diseases such as enterotoxigenic E. coli and Salmonella (Yolken et al., 1988; Ikemori et al., 1992; Karlsson et al., 2004). Therefore, IgY is a potential substitute for antibiotics or vaccine.

Helicobacter pylori infection is frequently observed in adults worldwide and causes gastric and duodenal ulcers, gastric lymphoma, and possibly gastric carcinomas (Shin et al., 2002; Chu et al., 2003). Neutralization of highly acidic environment by secreted urease leads to Helicobacter spp. survival in stomach, which penetrates and damages the mucus (Shin et al., 2003; Yang et al., 2012). Therefore, the urease can be a potential diagnostic and therapeutic target by developing anti-H. pylori IgY to prevent and cure the H. pylori associated stomach diseases (Shin et al., 2004). Although multiple antibiotic treatments eradicate most Helicobacter pylori (H. pylori) infections, therapy fails in $10-15 \%$ of cases due to the development of drug resistance (Suzuki et al., 2004). Consequently, it is important that new, more broadly based therapies for the treatment of $H$. pylori infection should be identified. The aim of this study was to evaluate the efficacy of three methods for purification of anti-H. pylori IgY from the egg yolks produced by White Leghorn laying hens capable of a high production of eggs and then to establish the method for producing highly purity $(>90 \%)$ of anti-Helicobacter pylori IgY from White Leghorn hens.

\section{Materials and Methods}

\subsection{Immunization}

White Leghorn hens (52 weeks old, $\mathrm{n}=4$ ) were immunized with $10 \mathrm{mg}$ purified urease of Helicobacter pylori with aluminum hydroxide gel adjuvant (Sigma-Aldrich) through wing muscle injections for 3 times at 2-week intervals following the first injection. Before and after antigen injection, the serum IgY titers were examined to confirm the increase of antibody titer against $H$. pylori. Then the eggs laid were collected daily for 6 months and stored at $4^{\circ} \mathrm{C}$. During the period of egg collection, the urease antigen was continuing injected into each hen every month.

\subsection{IgY Extraction}

After separating the yolks from egg white and puncturing the yolk sac with a needle, the contents were allowed to drip through a nylon mesh into a measuring cylinder, and then diluted with 10 -fold distilled water. IgY was precipitated by three methods. In the dextran sulphate method (Jensenius et al., 1981), the diluted yolk was then mixed with dextran sulphate $(\mathrm{MW}<500,000)$ (Sigma-Aldrich) containing $1 \mathrm{M} \mathrm{CaCl}_{2}$ and then centrifuged at $1,500 \mathrm{X} \mathrm{g}$ for $10 \mathrm{~min}$ at room temperature. The precipitate was dissolved with $\mathrm{PBS}$ and stored at $-20^{\circ} \mathrm{C}$. In the isopropanol method (Bade \& Stegemann, 1984), $100 \mathrm{~mL}$ of isopropanol were mixed with the diluted yolk solution for 4 hours at $4^{\circ} \mathrm{C}$. The mixture was centrifuged at 3,000 X g for $15 \mathrm{~min}$. to separate yolk fat. The pellet was washed thrice until pellet became white from yellow. The PBS with $0.01 \% \mathrm{NaN}_{3}$ was added to dissolve the precipitate at room temperature for $1 \mathrm{~h}$ and the solution was centrifuged at $8,500 \mathrm{Xg}$ and $25^{\circ} \mathrm{C}$ for 30 mins. The supernatant was finally filtered through No.1 filter paper. The filtrate was collected and stored at $-20^{\circ} \mathrm{C}$. In the extraction of water-soluble fraction with modified method reported by Kim and Nakai (1996); the diluted yolk was adjusted to $\mathrm{pH}=5.0$ with $0.1 \mathrm{~N} \mathrm{HCl}$, and stood at $4^{\circ} \mathrm{C}$ for $24 \mathrm{~h}$. The solution was centrifuged at $5,500 \mathrm{X} \mathrm{g}$ and $4^{\circ} \mathrm{C}$ for $1 \mathrm{hr}$. The supernatant was filtered through Whatman No. 52, followed by $0.45-\mu \mathrm{m}$ filter (Millipore) at $4^{\circ} \mathrm{C}$. The filtrate was collected and stored at $-20^{\circ} \mathrm{C}$.

\subsection{Purification of IgY by Affinity Chromatography and Ion Exchange Chromatography}

Total egg proteins of the previously prepared filtrates were precipitated by slowly addition of ammonium sulfate $\left[\left(\mathrm{NH}_{4}\right)_{2} \mathrm{SO}_{4}\right]$ to reach final concentration about $40 \%$. Next, the protein solution was centrifuged at 8,500 X $\mathrm{g}$ for 15 mins. and the pellet was dissolved in phosphate buffer $(\mathrm{pH}=7.8)$. Then, centrifugation was performed at $2,100 \mathrm{X} \mathrm{g}$ for15 mins. After dissolving the protein pellet with PBS, the protein solution in a membrane (Spectra/Por Cellulose Ester membrane MWCO: 100000) was dialyzed with PBS to remove the remaining salt (Hansen et al., 1998; Cook et al., 2001).

The IgY was purified by an affinity column (Econo-Pac Blue Cartridges) packed with DEAE Affi-gel with specific function group (Cibacron ${ }^{\circledR}$ Blue F3GA Cibacron Blue F3GA and (DEAE)-O $\left(\mathrm{CH}_{2}\right)_{2} \mathrm{~N}_{(}\left(\mathrm{CH}_{2} \mathrm{CH}\right)_{2} \mathrm{HCl}_{\text {) }}$ or an Macro-Prep ion exchange column (Econo-Pac High Capacity Ion Exchange Cartridges) with specific function group $\left(-\mathrm{SO}^{3-}\right)$. One $\mathrm{mL}$ of the protein solution was infused into the column and the $\mathrm{IgY}$ was eluted by buffer containing 1.4 M NaCl. In addition, the IgY was purified by an ion exchange column (Econo-Pac High Capacity Ion Exchange Cartridges) packed with Macro-Prep ion exchange supports with specific ligand. One ml of the sample was infused into the column and the IgY was then eluted with low salt buffer. The elutate from both methods was neutralized with $0.02 \mathrm{M}$ Tris- $\mathrm{HCl}(\mathrm{pH}=8.0)$ immediately. 


\subsection{Quantification, Purity, and Titer Determination of $\operatorname{Ig} Y$}

The total protein amount of the sample was determined using either the Biuret method or Lowry method (Lowry et al., 1951). The IgY purity was determined by SDS-PAGE. Equivalent amounts of proteins were boiled in sample buffer (2.5 mL 0.5 M Tris-HCl, pH 6.8; $4.0 \mathrm{~mL} \mathrm{10 \%} \mathrm{SDS;} 2.0 \mathrm{~mL}$ glycerol; $1.0 \mathrm{~mL} \beta$-mercaptoethanol (2-ME); and $0.5 \mathrm{~mL}$ distilled water for 5 minutes. $30 \mu \mathrm{g}$ of total proteins were separated by $4-8 \%$ polyacrylamide gel at 70 volt. Commercial IgY (Sigma) was used as the standard. The concentration of each band was determined using a densitometer (Helena, Model Bjf 00105, USA). The IgY antibody titers were measured with the ELISA method and commercial IgY was used as the standard. The relative purity and recovery was determined as follows: The relative purity $($ fold $)=$ the titer in steps/the titer in crude extract step. Recovery $(\%)=$ protein $\mathrm{x}$ titer in steps/(protein $\mathrm{x}$ titer in crude extract step).

The specificity of the IgY against the urease of $H$. pylori was evaluated by western blotting. When SDS-PAGE was finished, the proteins were transferred to polyvinylidene fluoride (PVDF) membranes (Millipore, MO, USA) The membranes were incubated in blocking buffer $(5 \%(\mathrm{w} / \mathrm{v})$ non-fat milk in PBS) at room temperature for $1 \mathrm{~h}$. After blocking, chick anti-H. pylori IgY was added at $1 / 100$ at $4{ }^{\circ} \mathrm{C}$ with gentle shaking overnight. The membrane was washed with PBST (per liter containing $2.9 \mathrm{~g} \mathrm{NaCl}, 0.2 \mathrm{~g} \mathrm{KCl}, 0.2 \mathrm{~g} \mathrm{KH}_{2} \mathrm{PO}_{4}, 0.2 \mathrm{~g}$ $\mathrm{Na}_{2} \mathrm{HPO}_{4} \cdot 12 \mathrm{H}_{2} \mathrm{O}, 0.5 \mathrm{~mL}$ Tween 20) for three times and then incubated with rabbit anti-chicken IgY antibody (Santa Cruz Biotechnology, CA, USA) at room temperature for $1 \mathrm{~h}$. Enhanced chemiluminescence (ECL) substrates reagents (PerkinElmer, MA, USA) was used to develop the fluorescent signals.

\section{Results and Discussion}

As major pathogen to cause gastric and duodenal ulcer and possibly gastric cancer, H. pylori can infect repeatedly more than $90 \%$ of adults (Chu et al., 2003). In this study, we established a procedure to produce the anti-H. pylori IgY through the eggs of White Leghorn hens. In egg, phospholipids and cholesterol of the fat accounts for about one-third of the yolk weight; proteins account for about $15-17 \%$ of the yolk weight and the IgY is major component in plasma protein (Powrie, 1976). Therefore, different methods, including extra-centrifugation (McBee \& Cotterilly, 1979), polyethylene glycol (Polson et al., 1985), polyacryl acid resins (Hamada et al., 1991), sodium dextran sulfate (Jensenius et al., 1981), carrageenan and xanthan gum (Hatta et al., 1990) have been developed to purify the proteins from the fats. In this study, we compared the efficiency of three extraction methods in extraction of the total proteins from egg yolks. The yields were $47.52 \%, 41.07 \%$ and $51.35 \%$ for the methods of dextran sulphate, isopropanol and water-soluble fraction (WSF), respectively (Table 1). Apparently, water soluble fraction method is the best method to extract the total proteins from the egg yolk.

Further, avian antibodies can be concentrated using different salts, such as ammonium sulphate (Akita \& Nakai, 1993), sodium sulphate (Wooley \& Landon, 1995) or caprylic acid (McLaren et al., 1994). IgY could reach the purity of $98.3 \%$ and yield of $73 \%$ by sodium sulfate precipitation (Hatta et al., 1990). In this study, we obtained a purity of $37-53 \%$ and titer of $22.6-29.5 \mathrm{unit} / \mathrm{mg}$ protein among these three methods by the optimal ammonia sulfate $\left(\left(\mathrm{NH}_{4}\right)_{2} \mathrm{SO}_{4}\right) \quad 45 \sim 55 \%$ (W/W). This result indicates that extraction method also affect the protein concentration by the salting precipitation. Following, there are many methods to purify the $\operatorname{IgY}$ from yolk (Schwarzkopf \& Thiele, 1996; Gee et al., 2003). Firstly, simple water dilution method is used to remove lipoproteins from WSF for the IgY purification (Jensenius et al., 1981; Kwan et al., 1991; Akita \& Nakai, 1992; 1993). This water dilution method has demonstrated as the best method to recover and purify the IgY with the highest purity of $34 \%$ in comparison with the methods of polyethylene glycol, dextran sulphate and chloroform (Verdoliva et al., 2000). However, the purity (74-78\%) of the IgY from WSF with water dilution method was lower than that (83-99\%) of the IgY from WSF with filter paper (Kim \& Nakai, 1998).

The IgY has been further purified from the WSF protein extracts by different processes, such as delipidation to extract the IgY from other livetins (Kim \& Nakai, 1998). Generally, affinity chromatography and ion exchange chromatography are the best methods to purify the IgY. Verdoliva et al. (2000) obtained the highest yield of the $\operatorname{IgY}(10.2 \mathrm{mg} / \mathrm{mL})$ and the best purity (> 90\%) from the WSF using TG19318/Emphaze and TG19318/Emphaze affinity column. Additionally, affinity chromatography with synthetic ligand could gain the $92.1 \%$ purity and the $78.2 \%$ recovery of the $\operatorname{IgY}$ (Dong et al., 2008). In the present study, we used affinity chromatography to get a purity of $85 \%$ at least for three extraction methods, even up to $90 \%$ for the WSF method (Table 1). Further purification with ion exchange chromatography only increased slightly the purity of $2-4 \%$. These results suggest that one step of affinity chromatography is enough to purify the $\operatorname{IgY}$ costly and efficiently. Further, we characterized the antibodies obtained between affinity chromatography and ion exchange chromatography. The purity, relative purification fold and titer were $85-90 \%, 19.63-34.61$ and 223.8-273.4 unit/mg protein for affinity chromatography and $89-92 \%, 25.33-47.14$, and $288.8-372.4$ unit/mg for ion exchange chromatography 
respectively (Table 1, Figure 1). Finally we found high specificity of the IgY against the urease of $H$. pylori by western blot analysis (Figure 2). Here, we established a procedure to extract and purify the anti-H. pylori IgY from the eggs of White Leghorn hens. This procedure combines sequentially water-soluble fraction (WSF) method, water dilution, ammonium sulfate salting and affinity column. Anti-H. pylori IgY can be used to prevent and cure the $H$. pylori infection.

Table 1. Titer and purity of IgY obtained from the egg yolk of White Leghorn hen after purified steps

\begin{tabular}{|c|c|c|c|c|c|c|c|c|c|c|c|c|c|c|c|}
\hline \multirow{2}{*}{$\begin{array}{l}\text { Technique } \\
\text { Methods }\end{array}$} & \multicolumn{3}{|c|}{$\begin{array}{l}\text { Protein } \\
\text { (mg) }\end{array}$} & \multicolumn{3}{|c|}{$\begin{array}{c}\text { IgY titer } \\
\text { (U/mg protein) }\end{array}$} & \multicolumn{3}{|c|}{ Relative purity (fold) } & \multicolumn{3}{|c|}{$\begin{array}{c}\text { Purification } \\
(\%)\end{array}$} & \multicolumn{3}{|c|}{$\begin{array}{c}\text { Recovery } \\
(\%)\end{array}$} \\
\hline & 1 & 2 & 3 & 1 & 2 & 3 & 1 & 2 & 3 & 1 & 2 & 3 & 1 & 2 & 3 \\
\hline Crude extract & $\begin{array}{c}1687 \\
(47.52 \%)\end{array}$ & $\begin{array}{c}1458 \\
(41.07 \%)\end{array}$ & $\begin{array}{c}1823 \\
(51.35 \%)\end{array}$ & 9.2 & 7.9 & 11.4 & 1 & 1 & 1 & - & - & - & 100 & 100 & 100 \\
\hline $\begin{array}{l}\text { Salting out } \\
\left(\mathrm{NH}_{4}\right)_{2} \mathrm{SO}_{4}\end{array}$ & 58.33 & 55.70 & 61.24 & 26.2 & 29.5 & 22.6 & 2.85 & 3.73 & 1.98 & 45 & 53 & 37 & 9.85 & 14.3 & 6.66 \\
\hline $\begin{array}{c}\text { Affinity } \\
\text { Chromatography }\end{array}$ & 2.65 & 2.26 & 2.80 & 247.1 & 273.4 & 223.8 & 26.86 & 34.61 & 19.63 & 87 & 85 & 90 & 4.22 & 3.02 & 3.02 \\
\hline $\begin{array}{c}\text { Ion Exchange } \\
\text { Chromatography }\end{array}$ & 1.60 & 1.55 & 1.72 & 319.0 & 372.4 & 288.8 & 34.67 & 47.14 & 25.33 & 90 & 89 & 92 & 3.29 & 5.01 & 2.39 \\
\hline
\end{tabular}

Egg contains protein amount of $3.55 \mathrm{~g} /$ yolk

Used 10 eggs in this analysis

Method 1: dextran sulphate

Method 2: isopropanol

Method 3: water-soluble fraction

Relative purity (fold) $=$ the titer in steps/the titer in crude extract step.

Purification (\%): The IgY purity was determined by SDS-PAGE and examined using a densitometer.

Recovery $(\%)=$ protein $\mathrm{x}$ titer in steps/protein $\mathrm{x}$ titer in crude extract step.

$\begin{array}{lcccccc}\text { M } & 1 & 2 & 3 & 4 & 5 & 6 \\ \text { Std } & \text { Aff Dex } & \text { Aff Iso } & \text { Aff WSF } & \text { Ion Dex } & \text { Ion Iso } & \text { Ion WSF }\end{array}$

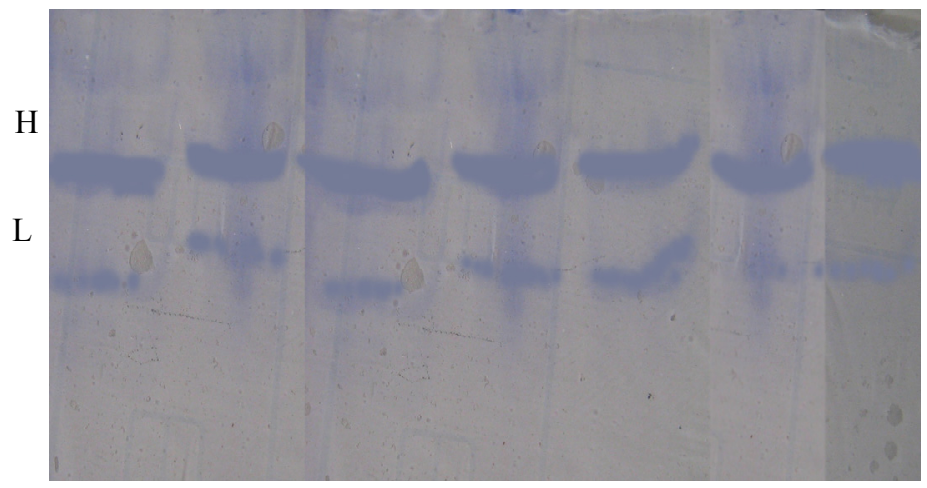

Figure 1. SDS-PAGE analysis of anti-H. pylori IgY purified by after affinity chromatography and ion exchange chromatography

After gel electrophoris in reduced condition, IgY was separated into two polypeptides of $\sim 67 \mathrm{Kda}$ (heavy chain, H) and $\sim 30 \mathrm{Kda}$ (light chain, L). M: IgY standard. Lane 1: IgY purified by dextran sulphate and affinity chromatography; Lane 2: IgY purified by isopropanol and affinity chromatography; Lane 3: IgY purified by water-soluble fraction and affinity chromatography; Lane 4: IgY purified by dextran sulphate and ion exchange chromatography: Lane 4: IgY purified by isopropanol and ion exchange chromatography and Lane 6: IgY purified by water-soluble fraction and ion exchange chromatography. 


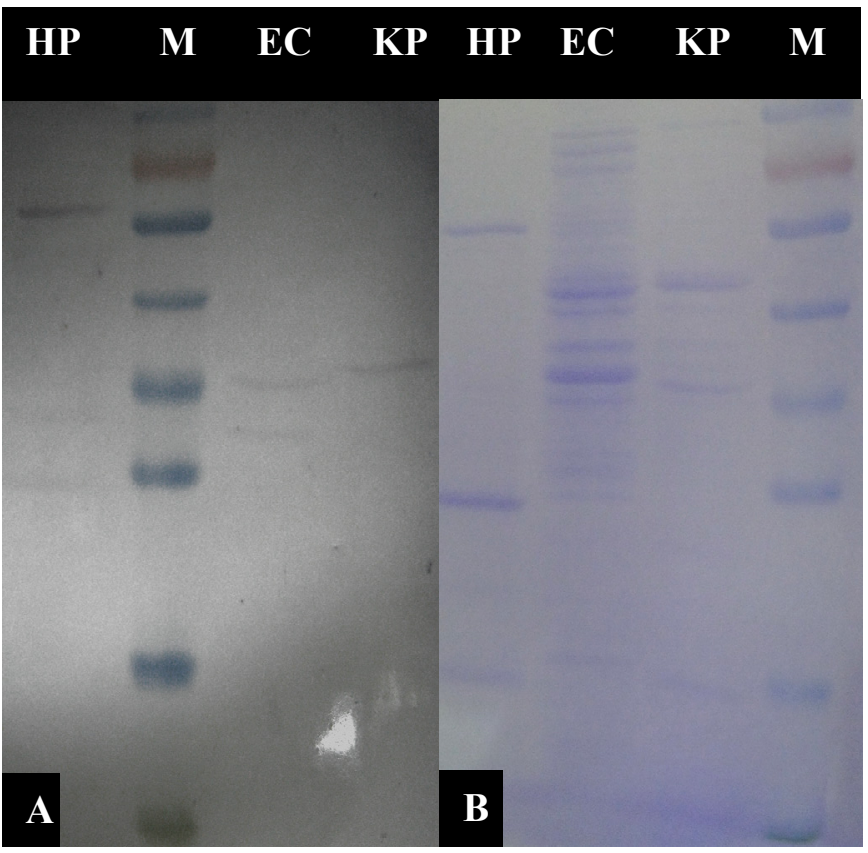

Figure 2. Characterization of chicken IgY against the urease of Helicobacter pylori by Western blot analysis (A) and SDS-PAGE gel analysis (B). M: Protein size marker, HP indicates the urease of Helicobacter pylori, EC represents E. coli, and KP means Klebsiella pneumoniae

\section{Conclusion}

We used White Leghorn hens to produce the anti-H. pylori IgY eggs. Among three extraction methods of dextran sulphate, isopropanol and water-soluble fraction (WSF), WSF method was the best method to recover and purify the total proteins. Further, high purity of the IgY could be obtained by ammonia sulfate precipitation and affinity chromatography and/or ion exchange chromatography.

\section{References}

Akita, E. M., \& Nakai, S. (1992). Immunoglobulin from egg yolk: isolation and purification. J. Food Sci., 57, 629-634. http://dx.doi.org/10.1111\%2Fj.1365-2621.1992.tb08058.x

Akita, E. M., \& Nakai, S. (1993). Comparison of four purification methods for the production of immunoglobulin from eggs laid by hens immunized with an enterotoxigenic E. coli strain. J. Immunol. Methods, 160, 207-262. http://dx.doi.org/10.1016\%2F0022-1759\%2893\%2990179-B

Bade, H., \& Stegemann, H. (1984). Rapid method of extraction of antibodies from hen egg yolk. J. Immunol. Methods, 72, 421-426. http://dx.doi.org/10.1016\%2F0022-1759\%2884\%2990010-3

Chu, C. S., Yu, Y. Y., Kong, M. S., \& Ou, J. T. (2003). Rate of Helicobacter pylori infection in children and clonality of Taiwan strains. Microbiol. Immunol., 47, 813-821.

Cook, C. L., Pao, W., Firca, J. R., Anderson, B. E., \& Fryer, J. P. (2001). Simple purification methods for an alphagalactose-specific antibody from chicken eggs. J. Biosci. Bioengineer., 1, 305-310. http://dx.doi.org/10.1016\%2FS1389-1723\%2801\%2980139-0

Davalos-Pantoja, L., Ortega-Vinuesa, J. L., Bastos-Gonzalez, D., \& Hidalgo-Alvarez, R. (2000). A comparative study between the absorption of IgY and IgG on latex particles. Biomater. Sci. Polym. Ed., 11, 657-673.

Dong, D., Liu, H., Xiao, Q., \& Li, R. (2008). Affinity purification of egg yolk immunoglobulins (IgY) with a $\begin{array}{lllllll}\text { stable synthetic ligand. } J . & \text { Chromatography } & B, & 870, & 51-54 .\end{array}$ http://dx.doi.org/10.1016\%2Fj.jchromb.2008.05.036

Gee, S. C., Bate, I. M., Thomas, T. M., \& Rylatt, D. B. (2003). The purification of IgY from chicken egg yolk by preparative electrophoresis. Protein Expres. Purific., 30, 151-155. http://dx.doi.org/10.1016\%2FS1046-5928\%2803\%2900076-7 
Hamada, S., Honkoshi, T., Minami, T., Kawabata, S., Hiraoka, J., Fujiwara, T., \& Ooshima, T. (1991). Oral passive immunization against dental caries in rats by use of hen egg yolk antibodies specific for cell-associated glucosyltransferase of Streptococcus mutans. Inflammat. Res., 59, 4161-4167. http://dx.doi.org/10.1159\%2F000261376

Hansen, P., Scoble, J. A., Hanson, B., \& Hoogenraad, N. J. (1998). Isolation and purification of immunoglobulins from chicken eggs using thiphilic interaction chromatography. J. Immunol. Methods, 215, 1-7. http://dx.doi.org/10.1016\%2FS0022-1759\%2898\%2900050-7

Hatta, H., Kim, M., \& Yamamoto, T. (1990). Novel isolation method for hen egg yolk antibody, "IgY". Agri. Biology Chem., 54, 2531-2535. http://dx.doi.org/10.1271\%2Fbbb1961.54.2531

Ikemori, Y., Kuroki, M., Peralta, R. C., Yokoyama, H., \& Kodama, Y. (1992). Protection of neonatal calves against fatal enteric colibacillus by administration of egg yolk powder from hens immunized with k99-pilated enterotoxigenic Escherichia coli. Am. J. Vet. Res., 53, 2005-2008.

Jensenius, J. C., Andersen, I., Hau, J., Crone, M., \& Koch, C. (1981). Eggs: conveniently packed antibodies. Methods for purification of yolk IgG. J. Immunol. Methods, 46, 63-68. http://dx.doi.org/10.1016\%2F0022-1759\%2881\%2990333-1

Karlsson, M., Kollberg, H., \& Larsson, A. (2004). Chicken IgY: utilizing the evolutionary advantage. Worlds Poult. Sci. J., 60, 341-347. http://dx.doi.org/10.1079\%2FWPS200422

Kim, H., \& Nakai, S. (1996). Immunoglobulin separation from egg yolk: a serial filtration system. J. Food Sci., 61, 510-513. http://dx.doi.org/10.1111\%2Fj.1365-2621.1996.tb13144.x

Kim, H., \& Nakai, S. (1998). Simple separation of immunoglobulin from egg yolk by ultrafiltration. J. Food Sci., 63, 485-490. http://dx.doi.org/10.1111\%2Fj.1365-2621.1998.tb15769.x

Ko, K. Y., \& Ahn, D. U. (2007). Preparation of immunoglobulin Y from egg yolk using ammonium sulfate precipitation and ion exchange chromatography. Poult. Sci., 86, 400-407.

Kwan, L., Chan, E. L., Helbig, N., \& Nakai, S. (1991). Fractionation of water-soluble and -insoluble components from egg yolk with minimum use of organic solvents. J. Food Sci., 56, 1537-1541.

Lowry, O. H., Rosebrough, N. J., Farr, L., \& Randall, J. (1951). Protein measurement with Folin-phenol reagent. J. Biology Chem., 193, 265-275.

Mcbee, L. E., \& Cotterill, O. J. (1979). Ion-exchange chromatography and electrophoresis of egg yolk proteins. J. Food Sci., 44, 656-660.

McLaren, R. D., Prosser, C. G., Grieve, R. C., \& Borissenko, M. (1994). The use of caprylic acid for the extraction of the immunoglobulin fraction from egg yolk of chicken immunized with ovine a-lactalbumin. $J$. Immunol. Methods, 177, 175-184. http://dx.doi.org/10.1016\%2F0022-1759\%2894\%2990154-6

Polson, A., Coetzer, T., Kruger, J., Maltzahn, E. V., \& Merwe, K. J. (1985). Improvements in the isolation of IgY from the yolks of eggs laid by immunized hens. Immunol. Investigat., 14, 323-327. http://dx.doi.org/10.3109\%2F08820138509022667

Powrie, W. D. (1976). Characteristics of edible fluids of animal origin: eggs. In: Principles of food science. Part 1. Food Chem., 7, 124-129.

Reilly, M. R., Domingo, R., \& Sandhu, J. (1997). Oral delivery of antibodies: future pharmacokinetic trends. Clin. Pharmacokinetics, 32, 313-323. http://dx.doi.org/10.2165\%2F00003088-199732040-00004

Rose, M. E., Orlans, E., \& Buttress, N. (1974). Immunoglobulin classes in the hen's egg their segregation in yolk and white. Europ. J. Immunol., 4, 521-523. http://dx.doi.org/10.1002\%2Feji.1830040715

Schwarzkopf, C., \& Thiele, B. (1996). Effectivity of different methods for the extraction and purification of IgY. ALTEX 13, 35-39.

Shin, J., Yang, M., Nam, S. W., Kim, J. T., Myung, N. H., Bang, W., \& Roe, I. H. (2002). Use of egg yolk-derived immunoglobulin as an alternative antibiotic treatment for control of Helicobacter pylori infection. Clin. Vaccine Immunol., 9, 1061-1066. http://dx.doi.org/10.1128\%2FCDLI.9.5.1061-1066.2002

Shin, J., Nam, S., Kim, J., Yoon, J., Bang, W., \& Roe, I. (2003). Identification of immunodominant Helicobacter pylori proteins with reactivity to H. pylori-specific egg-yolk immunoglobulin. J. Med. Microbiol, 52, 217-222. http://dx.doi.org/10.1099\%2Fjmm.0.04978-0 
Shin, J. H., Roe, I. H., \& Kim, H. G. (2004). Production of anti-Helicobacter pylori urease-specific immunoglobulin in egg yolk using an antigenic epitope of H. pylori urease. J. Med. Microbiol., 53, 31-34. http://dx.doi.org/10.1099\%2Fjmm.0.05327-0

Suzuki, H., Nomura, S., Masaoka, T., Goshima, H., Kamata, N., Kodama, Y., Ishii, H., ... Hibi, T. (2004). Effect of dietary anti-Helicobacter pylori-urease immunoglobulin $\mathrm{Y}$ on Helicobacter pylori infection. Aliment. Pharmacol. Therapeut., 1, 185-192. http://dx.doi.org/10.1111\%2Fj.1365-2036.2004.02027.x

Tini, M., Jewll, U. R., Camenisch, G., Chilov, G., \& Gassmann, M. (2002). Generation and application of chicken egg-yolk antibodies. Comparat. Biochem. Physiol., 131, 569-574. http://dx.doi.org/10.1016\%2FS1095-6433\%2801\%2900508-6

Verdoliva, A., Basile, G., \& Fassina, G. (2000). Affinity purification of immunoglobulins from chicken egg yolk $\begin{array}{lllllll}\text { using a new synthetic ligand. J. Chromatography } & \text { B., } & 749, & \text { 233-242. }\end{array}$ http://dx.doi.org/10.1016\%2FS0378-4347\%2800\%2900426-6

Wooley, J. A., \& Landon, J. (1995). Comparison of antibody production to human interleukin-6 (IL-6) by sheep and chickens. J. Immunolog. Methods, 178, 253-265.

Yang, Y. H., Park, D., Yang, G., Lee, S. H., Bae, D. K., Kyung, J., Kim, D., Choi, E. K., ... Kim, Y. B. (2012). Anti-Helicobacter pylori effects of IgY from egg york of immunized hens. Lab. Animal Res., 28, 55-60. http://dx.doi.org/10.5625\%2Flar.2012.28.1.55

Yokayama, H., Peralta, R. C., Diaz, R., Sendo, S., \& Ikemori, Y. (1992). Passive protective effect of chicken egg yolk immnoglobins against experimental enterotoxigenic Escherichia coli infection in neonatal piglets. Infect. Immunity, 60, 998-1007.

Yolken, R. H., Leister, F., Wee, S. B., Miskuff, R., \& Vonderfecht, S. (1988). Antibodies to rotavirus in chicken's eggs: a potential source of antiviral immunoglobulins suitable for human consumption. Pediatrics, 81, 291-295. http://dx.doi.org/10.1172\%2FJCI113821

Zhang, W. W. (2003). The use of gene-specific IgY antibodies for drug target discovery. Drug Disc. Today, 8 , 364-371. http://dx.doi.org/10.1016\%2FS1359-6446\%2803\%2902655-2 